\title{
KEBIJAKAN NEGARA TERKAIT PERKEMBANGAN DAN REVITALISASI INDUSTRI PERTAHANAN INDONESIA DARI MASA KE MASA
}

\author{
Endro Tri Susdarwono ${ }^{1}$, Ananda Setiawan ${ }^{2}$, Yonimah Nurul Husna ${ }^{3}$ \\ ${ }^{1}$ FISIP, Universitas Peradaban, Brebes \\ ${ }^{2}$ FEB, Universitas Terbuka, Pekalongan \\ ${ }^{3}$ Peneliti Independen \\ susdarwonoendrotri@gmail.com
}

\begin{abstract}
Abstrak
Tujuan penelitian ini membahas mengenai kebijakan Negara terkait perkembangan dan revitalisasi Industri Pertahanan Indonesia dari masa ke masa. Penelitian ini merupakan penelitian hukum normatif, tipe penelitiannya menggunakan kajian komprehensif analitis dan pendekatannya normatif analitis. Pemerintah memberikan perhatian kepada industri pertahanan dalam negeri dengan membentuk tim, dewan dan badan yang pada prinsipnya untuk mempercepat pembangunan industry pertahanan nasional. Pembentukan tim, dewan, dan badan dilakukan dengan beberapa Keputusan Presiden (Keppres) Nomor 40 Tahun 1980 tentng Tim Pembina Industri Hankam, Nomor 6 Tahun 1984 tentang Dewan Pembina Industri Strategis, Nomor 44 Tahun 1989 tentang Badan Pembina Industri Strategis, Nomor 56 Tahun 1989 tentang Dean Pembina Industri Strategis, Nomor 64 Tahun 1998 tentang Badan Pengelola BUMN dan Penetapan PT BPIS. Perjalanan industry pertahanan Indonesia mengalami pasang surut sampai akhirnya terjadi krisis pada tahun 1998 seiring dengan krisis eknomi yang melanda Indonesia. Dengan terjadinya krisis, maka pada tahun 2001 dengan memperhatikan banyak BUMN yang tumbang, maka PT BPIS dibubarkan. Kebijakan revitalisasi Industri Pertahanan di awali dengan pembentukan Komite Kebijakan Industri Pertahanan (KKIP) melalui Peraturan Presiden Nomor 42 Tahun 2010 disusul dengan lahirnya Undang-Undang Nomor 16 Tahun 2012 tentang Industri Pertahanan. Salah satu amanat Undang-undang terseut adalah pembentukan KKIP yang kemudian dikukuhkan dengan Keppres nomor 59 tahun 2013.
\end{abstract}

Kata kunci: industri pertahanan, kebijakan; revitalisasi 
e-ISSN : 2621-4105

\title{
STATE POLICIES RELATING TO THE DEVELOPMENT AND REVITALIZATION OF THE INDONESIAN DEFENSE INDUSTRY FROM TIME TO TIME
}

\author{
Endro Tri Susdarwono ${ }^{1}$, Ananda Setiawan ${ }^{2}$, Yonimah Nurul Husna ${ }^{3}$ \\ ${ }^{1}$ FISIP, Universitas Peradaban, Brebes \\ ${ }^{2}$ FEB, Universitas Terbuka, Pekalongan \\ ${ }^{3}$ Peneliti Independen \\ susdarwonoendrotri@gmail.com
}

\begin{abstract}
The purpose of this study is to discuss State policies related to the development and revitalization of the Indonesian Defense Industry from time to time. This research is a normative legal research, the type of research uses a comprehensive analytical study and analytical normative approach. The government pays attention to the domestic defense industry by forming teams, councils and bodies in principle to accelerate the development of the national defense industry. The formation of teams, councils, and bodies was carried out with number 40 of Presidential Decrees (Keppres) of 1980 concerning the Defense and Security Industry Development Team, Number 6 of 1984 concerning the Strategic Industrial Board of Trustees, Number 44 of 1989 concerning the Strategic Industrial Board of Trustees, Number 56 of 1989 concerning Board of Strategic Industry Advisors, Number 64 of 1998 concerning the Management Body of BUMN and Settlement of PT BPIS. The journey of Indonesia's defense industry experienced ups and downs until finally a crisis occurred in 1998 along with the economic crisis that hit Indonesia. With the crisis, in 2001 with regard to many BUMN that were uprooted, PT BPIS was dissolved. The revitalization policy of the Defense Industry began with the establishment of the Defense Industry Policy Committee (KKIP) through Presidential Regulation Number 42 of 2010 followed by the birth of Law Number 16 of 2012 concerning the Defense Industry. One of the mandates of the law is the establishment of the KKIP which was later confirmed by Presidential Decree number 59 of 2013.
\end{abstract}

Keywords: defense industry; policy; revitalization 


\section{A. PENDAHULUAN}

Membangun sebuah sistem pertahanan nasional yang kuat, paling tidak membutuhkan pertimbangan pada empat hal berikut: faktor geografis negara yang bersangkutan, sumber daya nasional sebuah negara, analisis terhadap kemungkinan ancaman yang akan muncul, dan perkembangan teknologi informasi. ${ }^{1}$

Kerjasama pertahanan tidak bisa terelakkankarenasituasi lingkungan strategis yang tidak menentu dankesamaan kepentingan strategis. ${ }^{2}$ Dalam konteks global saat ini ancaman terhadap kedaulatan negara telah berkembang sejalan dengan perkembangan teknologi.Teknologi pertahanan selalu dianggap mewakili kekinian karena senantiasa didorong oleh kemampuan penangkalan untuk dapat menjawabtuntutan danmerespon ancaman yang selaluberubah.Oleh karena itu, produk pertahanan selalu menjadi state of the art.Dalam konteks tersebut, suatu negara yang memiliki industri pertahanan yang mapan dianggap memiliki sebuah keuntungan strategis dalam tatanan global. ${ }^{3}$

MEF (Minimum Essential Force) merupakan standar penting dan minimum dari kekuatan yang harus ditetapkan sebagai prasyarat mendasar agar TNI (Tentara Nasional Indonesia) dapat menjalankan misinya secara efektif dalam menghadapi ancaman yang sebenarnya. Salah satu sarana untuk mewujudkan MEF adalah melalui pengembangan industri militer dalam negeri. Optimalisasipengembanganindustri pertahanan nasional baru diberlakukan sejak 2010 melalui Kebijakan Umum Pertahanan Negara(Jakum

${ }^{1}$ Jerry Indrawan, "Perubahan Paradigma Pertahanan Indonesia Dari Pertahanan Teritorial Menjadi Pertahanan Maritim: Sebuah Usulan”, Jurnal Pertahanan Vol 4 No 5 Agustus 2015, hal. 93.

2 Beni Sukadis, "Peran Diplomasi Pertahanan Indonesia Dalam Kerjasama Pertahanan Indonesia Dan Amerika Serikat”, Jurnal Ilmu Hubungan Internasional Mandala Vol 1 No 1 JanuariJuni 2017, hal. 114.

3 Kina Media Ekuitas Produk Indonesia, "Disahkannya UU Industri PertahananTonggak Bangkitnya Industri Pertahanan Lokal" Edisi 2 Tahun 2012, hal. 6. 
Hanneg) 2010-2014, dan akanberlanjut selama dua periode lima-tahun lagi (sampai 2024). ${ }^{4}$

Industri pertahanan dalam negeri menjadi salah satu ujung tombak upaya sebuah negara dalam mengembangkan sistem pertahanan secara mandiri. Hal ini terkait dengan terpenuhinya kebutuhan baik dalam konteks penyediaan kualitas maupun kuantitas alutsistayang sesuai dengan karakteristik kewilayahan serta menghilangkan ketergantungan secara politis terhadap negara lain. Pembinaan industri pertahanan domestik telah terbukti dapat menjadi tulang punggung bagi pembangunan sistem pertahanan dan modernisasi alutsistaChina dan India yang saat ini tumbuh menjadi kekuatan militer besar di Asia. Berkaca kepada hal tersebut,Indonesia yang saat ini tengah mengakselerasi program untuk memenuhi kebutuhan minimum kekuatan militernya mengeluarkan dasar hukum bagi pengembanganindustri pertahanan dalam negeri melalui Undang-UndangNomor 16 Tahun 2012 tentang Industri Pertahanan. ${ }^{5}$

Industri pertahanan nasional harus mampu mengambil manfaat dari program pengadaan sarana pertahanan di Kemhan. Perlu ada konsensus nasional yang berpihak kepada pengembangan kapasitas industri pertahanan nasional agar dapat memiliki kompetensi inti yang kompetitif di level regional dan global. Konsensus ini diwujudkan dalam optimalisasi kerjasama antar lembaga terkait langsung dengan pengadaan alutsista, khususnya Kementerian Pertahanan, TNI, dan pihak-pihak produsen di dalam negeri dalam rangka membangun sarana pertahanan berbasis industri pertahanan dalam negeri. ${ }^{6}$

4 Lukman Fahmi Djarwono, "Pembangunan Industri Pertahanan Indonesia: Menuju Pemenuhan Target MEF atau Sekedar Menuju Arm Candy?", Jurnal Defendonesia Vol 2 No 2, Juni 2017, hal. 25.

5 Angga Nurdin Rachmat, "Tantangan dan Peluang Perkembangan Teknologi Pertahanan Global Bagi Pembangunan Kekuatan Pertahanan Indonesia”, Jurnal Pertahanan Vol 5 No 1, Juni 2017, hal. 205.

${ }^{6}$ Ian Montratama, "Strategi Optimalisasi Pengadaan Sarana Pertahanan Bagi Industri Pertahanan Indonesia,” Jurnal Pertahanan Vol 04 No 3, Desember 2014, hal. 79. 
Pengelolaan industri strategis dan industri pertahanan di banyak negara hampir selalu dihadapkan pada tiga permasalahan utama, yakni: Pertama, pengembangan teknologi pertahanan yang bergantung pada dua skema, yakni skema penguatan penelitan dan pengembangan industri pertahanannya, dan melalui skema offsetdan transfer teknologi. Kedua, pendanaan industri pertahanan dengan berbagai model pendanaan, dan yang ketiga permasalahan peningkatan kualitas Sumber Daya Manusia (SDM) industri pertahanan. Ketiganya berkaitan satu dengan yang lain dalam menyokong kebutuhan Alat Utama Sistem Persenjataan (Alutsista) dalam negerinya atau tengah beranjak menjadi pengekspor persenjataan dan alat perang. ${ }^{7}$

Abad ke-21 mencatat adanya peningkatan fenomena globalisasi industri pertahanan yang telah menguat sejak tahun 1970-1980an. Hal itu ditandai dengan terjadinya tren yang signifikan dalam intensivitas kerja sama negaranegara di dunia dalam membangun industri pertahanannya. ${ }^{8}$ Bahkan, negaranegara maju, sejak saat itu, lebih memilih membangun industrinya melalui kerja sama dengan negara lain dibandingkan melakukannya secara mandiri karena adanya pengurangan biaya yang signifikan. Hal ini tidak terlepas dari pelbagai tren kebijakan pengetatan anggaran, peningkatan biaya penelitian dan pengembangan (research and development/R\&D), dan peningkatan intensitas persaingan di pasar industri pertahanan. ${ }^{9}$ Globalisasi industri pertahanan yang membawa pada perubahan dinamika pengadaan persenjataan dari autarki (pengadaanyang bersifat independen) menjadi interdependensi, disebut sebagai salah satu fenomena intensifnya kerja sama dan kolaborasi dalam memproduksi persenjataan. ${ }^{10}$

\footnotetext{
${ }^{7}$ Muradi, "Model Pendanaan Industri Pertahanan dan Peningkatan Sumber Daya Manusia," Jurnal Pertahanan Vol 05 No 2, Agustus 2015, hal. 213.

${ }^{8}$ Jonathan D. Caverley, "United States Hegemony and the New Economics of Defense", Journal of Security Studies Vol 16 No. 4, Oktober-Desember 2007, hal. 600.

${ }^{9}$ Richard A. Bitzinger, The Modern Defene Industry: Political, Economic, and Technological Issues (California: ABC CLIO, 2009), hal. 6

${ }^{10}$ Mary Kaldordan Ulrich Albrecht, The End of Military Fordism: Restructuring the Global Military Sector (London: United Nations University, 1998), hal. 10.
} 
Realita evolusi industri pertahanan membuat pemahaman akan bela negara harus berevolusi pula. Tidak hanya sekedar memahami adanya pertahanan nirmiliter, namun pemahaman mengenai prosedur industrial, diplomasi dan kerja sama, merupakan salah satu kunci berbela negara masa kini. ${ }^{11}$

Berdasarkan latar belakang di atas penelitian ini lebih mengkaji tentang kebijakan Negara terkait perkembangan dan revitalisasi industry pertahanan di Indonesia dari masa ke masa.

\section{B. PERUMUSAN MASALAH}

Berdasarkan paparan di atas, penelitian ini berusaha untuk mencari jawaban atas pertanyaan bagaimana kebijakan Negara terkait perkembangan dan revitalisasi Industri Pertahanan Indonesia dari masa ke masa?

\section{METODE PENELITIAN/LANDASAN TEORITIS}

Penelitian ini termasuk penelitian hukum normatif yang hanya menggunakan data sekunder. Tipe penelitian hukumnya adalah kajian komprehensif analitis terhadap bahan hukum primer dan bahan hukum sekunder. Hasil kajian dipaparkan secara lengkap, rinci, jelas, dan sistematis sebagai karya ilmiah. Metode pendekatan yang digunakan adaah metode pendekatan yuridis normatif. Karena penelitian ini termasuk penelitian hukum normatif, pendekatannya menggunakan pendekatan normatif analitis, melalui pendekatan ini, artikel ini membahas mengenai aspek-aspek hukum yang berkaitan dengan kebijakan Negara tentang perkembangan dan revitalisasi industri pertahanan di Indonesia dengan mengikuti langkah-langkah sebagai berikut :

1) mengidentifikasi sumber hukum yang menjadi dasar rumusan masalah;

11 Denik Iswardani Witarti, dan Semmy Tyar Armandha, "Tinjauan Teoretis Konsepsi Pertahanan dan Keamanan Di Era Globalisasi Industri Pertahanan”, Jurnal Pertahanan Vol 5 No 3, Desember 2015, hal. 87-106. 
2) mengidentifikasi pokok bahasan dan subpokok bahasan yang bersumber dari rumusan masalah;

3) mengidentifikasi dan menginventarisasi ketentuan-ketentuan normatif bahan hukum primer dan bahan hukum sekunder berdasarkan rincian subpokok bahasan;

4) mengkaji secara komprehensif analitis bahan hukum primer dan bahan hukum sekunder guna menjawab permasalahan yang telah dirumuskan;

5) hasil kajian sebagai jawaban permasalahan dideskripsikan secara lengkap, rinci, jelas, dan sistematis dalam bentuk laporan hasil penelitian atau karya tulis ilmiah.

Spesifikasi penelitian dalam penelitian ini menggunakan deskriptif analitis, yaitu menguraikan hasil-hasil penelitian sesuai dengan permasalahan dan tujuan yang akan dicapai serta menganalisanya dari segi peraturan perundangan yang berlaku. Metode pengumpulan data menggunakan : studi pustaka ( bibliography study), dokumen (document study), dan studi arsip (file or record study).

Analisis data (analyzing), yaitu menguraikan data dalam bentuk kalimat yang baik dan benar, sehingga mudah dibaca dan diberi arti (diinterpretasikan) sehingga hasil analisis data memudahkan pengambilan kesimpulan secara induktif. Bahan hukum (data) hasil pengolahan tersebut dianalisis secara kualitatif dan kemudian dilakukan pembahasan. Berdasarkan hasil pembahasan kemudian diambil kesimpulan sebagai jawaban terhadap permasalahan yang diteliti.

\section{PEMBAHASAN}

\section{Kebijakan Negara Terkait Perkembangan Industri Pertahanan Masa Pertama}

Keputusan Presiden Nomor 59 Tahun 1983 tentang Pembentukan Dewan Pembina dan Pengelola Industri-Industri Strategis dan Industri pertahanan Keamanan menjadi tonggak pembentukan industry pertahanan di Tanah Air. Bernaung di dalamnya suatu wadah yang disebut badan usaha milik negara industry strategis (BUMNIS), yng mandiri dan secara politis padanya termaktub 
kepentingan pertahanan. Beleid ini menetapkan industry pertahanan bidang kedirgantaraan ditangani PT Dirgantara Indonesia (dulu PT IPTN), bidang kemaritiman ditangani PT PAL, bidang persenjataan dan amunisi ditangani PT PIndad, dan bidang bahan peledak ditangai PT Dahana. Keempat industry strategis terssebut merupakan bagian dri sepuluh industry strategsi, yang juga meliputi PT Inka (Industri Kereta Api), PT Inti di bidang telekomunikasi, PT Kraktau Steel (baja), PT Boma Bisma Indra (container dan peralatan ekspor), PT Barata (mesin disesel), dan PT LEN (elektronik). ${ }^{12}$

\section{Undang-Undang Nomor 5 Tahun 1984 tentang Perindustrian}

Menurut Undang-Undang Nomor 5 Tahun 1984 tentang Perindustrian, dijelaskan bahwa industri adalah kegiatan ekonomi yang mengolah bahan mentah, bahan baku, barang setengah jadi, dan/atau barang jadi menjadi barang dengan nilai yang lebih tinggi untuk penggunaannya, termasuk kegiatan rancang bangun dan perekayasaan industri. Rancang bangun industri adalah kegiatan industri yang berhubungan dengan perencanaan pendirian industri / pabrik secara keseluruhan atau bagian-bagian. Perekayasaan industri adalah kegiatan industri yang berhubungan dengan perancangan dan pembuatan mesin/peralatan pabrik dan peralatan industri lainnya.

Istilah industri sering diidentikkan dengan semua kegiatan ekonomi manusia yang mengolah barang mentah atau bahan baku menjadi barang setengah jadi atau barang jadi. Dari definisi tersebut, istilah industri sering disebut sebagai kegiatan manufaktur (manufacturing). Padahal, pengertian industri sangatlah luas, yaitu menyangkut semua kegiatan manusia dalam bidang ekonomi yang sifatnya produktif dan komersial. Karena merupakan kegiatan ekonomi yang luas maka jumlah dan macam industri berbeda-beda untuk tiap negara atau daerah. Pada umumnya, makin maju tingkat perkembangan perindustrian di suatu negara atau daerah, makin banyak

\footnotetext{
${ }^{12}$ Silmy Karim, Membangun Kemandirian Industri Pertahanan Indonesia (Jakarta : Kepustakaan Populer Utama, 2014), hal. 98.
} 
jumlah dan macam industri, dan makin kompleks pula sifat kegiatan dan usaha tersebut. Cara penggolongan atau pengklasifikasian industri pun berbeda-beda. Tetapi pada dasarnya, pengklasifikasian industri didasarkan pada kriteria yaitu berdasarkan bahan baku, tenaga kerja, pangsa pasar, modal, atau jenis teknologi yang digunakan. Selain faktor-faktor tersebut, perkembangan dan pertumbuhan ekonomi suatu negara juga turut menentukan keanekaragaman industri negara tersebut, semakin besar dan kompleks kebutuhan masyarakat yang harus dipenuhi, maka semakin beranekaragam jenis industrinya.

\section{Klasifikasi industri berdasarkan Surat Keputusan Menteri Perindustrian}

Selain pengklasifikasian industri tersebut di atas, ada juga pengklasifikasian industri berdasarkan Surat Keputusan Menteri Perindustrian Nomor 19/M/ I/1986 yang dikeluarkan oleh Departemen Perindustrian dan Perdagangan. Adapun pengklasifikasiannya adalah sebagai berikut :

a. Industri Kimia Dasar (IKD)

Industri Kimia Dasar merupakan industri yang memerlukan: modal yang besar, keahlian yang tinggi, dan menerapkan teknologi maju. Adapun industri yang termasuk kelompok IKD adalah sebagai berikut :

1) Industri kimia organik, misalnya: industri bahan peledak dan industri bahan kimia tekstil;

2) Industri kimia anorganik, misalnya: industri semen, industri asam sulfat, dan industri kaca;

3) Industri agrokimia, misalnya: industri pupuk kimia dan industri pestisida;

4) Industri selulosa dan karet, misalnya: industri kertas, industri pulp, dan industri ban. 
b. Industri Mesin Logam Dasar dan Elektronika (IMELDE)

Industri ini merupakan industri yang mengolah bahan mentah logam menjadi mesin-mesin berat atau rekayasa mesin dan perakitan. Adapun yang termasuk industri ini adalah sebagai berikut:

1) Industri mesin dan perakitan alat-alat pertanian, misalnya: mesin traktor, mesin hueler, dan mesin pompa;

2) Industri alat-alat berat/konstruksi, misalnya: mesin pemecah batu, buldozer, excavator, dan motor grader;

3) Industri mesin perkakas, misalnya: mesin bubut, mesin bor, mesin gergaji, dan mesin pres;

4) Industri elektronika, misalnya: radio, televisi, dan computer;

5) Industri mesin listrik, misalnya: transformator tenaga dan generator;

6) Industri kereta api, misalnya: lokomotif dan gerbong;

7) Industri kendaraan bermotor (otomotif), misalnya: mobil, motor, dan suku cadang kendaraan bermotor;

8) Industri pesawat, misalnya: pesawat terbang dan helicopter;

9) Industri logam dan produk dasar, misalnya: industri besi baja, industri alumunium, dan industri tembaga;

10) Industri perkapalan, misalnya: pembuatan kapal dan reparasi kapal;

11) Industri mesin dan peralatan pabrik, misalnya: mesin produksi, peralatan pabrik, the blower, dan kontruksi.

c. Aneka Industri (AI)

Industri ini merupakan industri dengan tujuan menghasilkan bermacam-macam barang kebutuhan hidup sehari-hari. Adapun yang termasuk industri ini adalah sebagai berikut:

1) Industri tekstil, misalnya: benang, kain, dan pakaian jadi;

2) Industri alat listrik dan logam, misalnya: kipas angin, lemari es, dan mesin jahit, televisi, dan radio;

3) Industri kimia, misalnya: sabun, pasta gigi, sampho, tinta, plastik, obat-obatan, dan pipa; 
4) Industri pangan, misalnya: minyak goreng, terigu, gula, teh, kopi, garam dan makanan kemasan;

5) Industri bahan bangunan dan umum, misalnya: kayu gergajian, kayu lapis, dan marmer.

d. Industri Kecil (IK)

Industri yang bergerak dengan jumlah pekerja sedikit, dan teknologi sederhana. Biasanya dinamakan industri rumah tangga, misalnya: industri kerajinan, industri alat-alat rumah tangga, dan perabotan dari tanah (gerabah);

e. Industri pariwisata

Industri ini merupakan industri yang menghasilkan nilai ekonomis dari kegiatan wisata. Bentuknya bisa berupa : wisata seni dan budaya (misalnya: pertunjukan seni dan budaya), wisata pendidikan (misalnya: peninggalan, arsitektur, alat-alat observasi alam, dan museum geologi), wisata alam (misalnya: pemandangan alam di pantai, pegunungan, perkebunan, dan kehutanan), dan wisata kota (misalnya: melihat pusat pemerintahan, pusat perbelanjaan, wilayah pertokoan, restoran, hotel, dan tempat hiburan);

\section{Peraturan Pemerintah Nomor 35 Tahun 1986}

Peraturan ini memuat tentang kewenangan pemerintah dalam pengaturan - pembinaan - pengembangan industri yang bersifat strategis dan penting untuk Pertahanan dan keamanan negara (HANKAMNEG).

\section{Kebijakan Negara Terkait Perkembangan Industri Pertahanan Masa Kedua}

\section{Pembentukan Bahana Pakarya Industri Strategis (BPIS)}

Dengan dikeluarkannya Peraturan Pemerintah No 52 Tahun 2002 pada tanggal 23 September 2002, maka PT Bahana Pakarya Industri Strategis (BPIS) Persero, secara resmi dibubarkan yang sebelumnya pada tahun 1998 dengan PP 35 Tahun 1998 diresmikan. PT BPIS merupakan holding company pertama 
dilingkungan Kementerian BUMN yang khusus menangangi Industri Strategis yang terdiri dari :

PT Dirgantara Indonesia (Industri Pesawat Terbang/Dirgantara)

PT PAL Indonesia (Industri Kapal)

PT Pindad (Industri Senjata/Pertahanan)

PT Dahana (Industri Bahan Peledak)

PT Krakatau Steel (Industri Baja)

PT Barata Indonesia (Industri Alat Berat)

PT Boma Bisma Indra (Industri Permesinan/Diesel)

PT Industri Kereta Api (Industri Kereta Api)

PT Industri Telekomunikasi Indonesia (Industri Telekomunikasi)

PT LEN Industri (Industri Elektronika dan Komponen)

Sebelumnya pada tahun 1989 dengan Keputusan Presiden No. 59 tahun 1989 telah dibentuk Lembaga Pemerintah Non Departemen (LPND) Badan Pengelola Industri Strategis (BPIS) yang ditugaskan untuk membina, mengelola dan mengembangkan sepuluh Industri Strategis diatas. Pembentukan BPIS LPND ini merupakan kelanjutan dari dikeluarkannya Keputusan Presiden No. 56 Tahun 1989 tentang Pembentukan Dewan Pembina Industri Strategis (DPIS) yang merupakan lembaga pembina BPIS. Akan tetapi kemudian pada tahun 1999 seiring dengan dikeluarkannya PP No 35 Tahun 1998, maka diterbitkan Keputusan Presiden RI Nomor 40 Tahun 1999 tentang Dewan Pembinan Industri Strategis (DPIS) pada tanggal 17 Mei 1999.

Keppres no. 40 tahun 1999 hingga saat ini belum dicabut, sehingga dengan demikian DPIS masih ada hanya hingga saat ini belum pernah melakukan rapat dan pertemuan, bahkan sekretariat DPIS yang seharusnya berada dikantor Menneg Ristrk/BPPT belum pernah dibuat.

Sejak dikembalikannya pembinaan BUMN Industri Strategis dari BPIS ke Kementrian Negara BUMN pada tahun 2002, maka pembinaanya menjadi wewenang Deputi Pertambangan, Industri Strategis, Energi dan Telekomunikasi (PISAT) dan Mentri Negara BUMN.

Kementrian negara BUMN didirikan berdasarkan UU no 17 tahun 2003 tentang Keuangan Negara dan UU no. 19 tentang BUMN yang kemudian 
ditindaklanjuti dengan PP No 41 tahun 2003, PP No 35 tahun 2005, PP No 43, No.44, No. 45 tahun 2005.

Sebelum BPIS LPND berdiri pada tahun 1989, Pembinaan dan pengelolaan BUMN Industri Strategis berada pada Departemen Terkait sehingga pembinaan dan pengelolannya belum terintegrasi denganbaik, kemudian pada tahun 1988 dengan dikeluarkannya Keputusan Presiden No. 44 tahun 1988 tentang Industri Strategis maka sepuluh industri diatas dinamakan BUMN Industri Strategis dengan tujuan pemerintah ingin membangun dan mengembangkan industri pertahanan dan kemandirian HANKAM.

Sejak tahun 1989 hingga 1998 (BPIS LPND dibubarkan), telah banyak dilakukan perencanaan program dan pembuatan road map pengembangan industri strategis sebagai ujung tombak industri pertahanan menuju kemandirian hankam dengan dua target atau sasaran utama yaitu menjadi Industri Maritim dan Industri Dirgantara terkemuka pada tahun 2015. Untuk menunjang hal ini maka kesepuluh industri strategis dikembangkan menjadi Pusat Unggulan Teknologi sesuai dengan jenis industrinya yaitu:

PT Dirgantara Indonesia Pusat Unggulan Industri Pesawat Terbang/Dirgantara

PT PAL Indonesia Pusat Unggulan Industri Maritim

Penujang Industri

PT Pindad Pusat Unggulan Industri Senjata/Pertahanan

PT Dahana Pusat Unggulan Industri Munisi

PT Krakatau Steel Pusat Unggulan Industri Baja

PT Barata Indonesia Pusat Unggulan Industri Alat Berat

PT Boma Bisma Indra Pusat Unggulan Industri Permesinan/Diesel

PT Industri Kereta Api Pusat Unggulan Industri Kereta Api

PT Industri Telekomunikasi Indonesia Pusat Unggulan Industri

Telekomunikasi

PT LEN Industri Pusat Unggulan ndustri Elektronika dan Komponen

Konsep pengembangan industri unggulan dengan sasaran Pusat Unggulan Industri Maritim dan Industri Dirgantara menjadi terhenti sejak reformasi berjalan pada tahun 1998, yang kemudian diikuti pembubaran BPIS LPND. Walaupun kemudian mencoba bangkit kembali dengan pendirian PT Pakarya 
Industri/PT BPIS Persero pada tahun 1998 yang kemudian dilikuidasi pada tahun 2002, tidak banyak lagi program pengembangan teknologi menuju kemandirian hankam dilakukan, karena dalam waktu yang cukup pendek (19982002) PT BPIS lebih banyak berkonsentrasi pada pembenahan masalah keuangan dan pendanaan yang dihadapi BUMN Industri Strategis.

Pembinaan dan arah pengelolaan BUMN Industri Strategis sejak 2002 hingga sekarang menjadi tidak fokus pada pengembangan industri hankam (maritim dan dirgantara) akan tetapi lebih banyak pada pengelolaan perusaaan BUMN persero yang menghasilkan keuntungan. Hal ini juga yang mengakibatkan banyak kegiatan pengembangan teknologi di BUMN Industri Strategis terhenti karena kurangnya pendanaan bantuan pemerintah dan tidak adanya road map pengembangan yang sinergi.

\section{Undang-Undang Nomor 3 Tahun 2002 tentang Pertahanan Negara}

Koordinasi Menteri Pertahanan dan Pimpinan kementerian lainnya dalam perencanaan strategis perencanaan sumber daya Nasional. Menhan menetapkan kebijakan pembinaan teknologi dan industry pertahanan, serta mendorong dan memajukan pertumbuhan industry pertahanan.

\section{Undang-Undang Nomor 18 Tahun 2002 tentang Sisnas Litbang Penerapan IPTEK}

Penguatan pertumbuhan industry berbasis teknologi memperkuat tarikan pasar.

\section{Undang-Undang Nomor 23 Tahun 2003 tentang BUMN}

BUMN menjadi perintis kegiatan usaha yang belum dapat dilaksanakan oleh sekotr swasta. Pemerintah dapat memberikan penugasan khusus kepada BUMN sesuai bidang usaha dan tujuannya.

\section{Undang-Undang Nomor 25 Tahun 2007 tentang Penanaman Modal}

Bidang usaha yang tertutup untuk penanaman Modal asing adalah produksi senjata, mesiu, alat peledak dan peralatan perang.

\section{Peraturan Pemerintah Nomor 35 Tahun 2007}


Badan usaha termasuk BUMNIS Pertahanan, mengalokasikan sebagian pendapatannya untuk mningkatkan kemampuan perekayasaan, inovasi, dan difusi teknologi dalam meningkatkan kinerja produksi dan/atau daya saing barang dan/atau jasa yang dihasilkan

\section{Perpres No. 28 Tahun 2008 tentang Kebijakan Industri Nasional}

Visi pembangunan Industri Nasional sebagaimana yang tercantum dalam Peraturan Presiden (Perpres) Nomor 28 Tahun 2008 tentang Kebijakan Industri Nasional adalah Indonesia menjadi Negara Industri Tangguh pada tahun 2025, dengan visi antara pada tahun 2020 sebagai Negara Industri Maju Baru, karena sesuai dengan Deklarasi Bogor tahun 1995 antar para kepala Negara APEC pada tahun tersebut liberalisasi di negara-negara APEC sudah harus terwujud.

Sebagai negara industri maju baru, sektor industri Indonesia harus mampu memenuhi beberapa kriteria dasar antara lain :

1. Memiliki peranan dan kontribusi tinggi bagi perekonomian Nasional;

2. IKM (Industri Kecil dan Menengah) memiliki kemampuan yang seimbang dengan Industri Besar;

3. Memiliki struktur industri yang kuat (Pohon Industri lengkap dan dalam);

4. Teknologi maju telah menjadi ujung tombak pengembangan dan penciptaan pasar;

5. Telah memiliki jasa industri yang tangguh yang menjadi penunjang daya saing internasional industrI;

6. Telah memiliki daya saing yang mampu menghadapi liberalisasi penuh dengan negara-negara APEC.

Diharapkan tahun 2020 kontribusi industri non-migas terhadap PDB

(Product Domestic Brutto) telah mampu mencapai 30\%, dimana kontribusi industri kecil (IK) ditambah industri menengah (IM) sama atau mendekati kontribusi industri besar (IB). Selama kurun waktu 2010 - 2020, industri harus tumbuh rata-rata 9,43\% dengan pertumbuhan IK, IM, dan IB masing-masing minimal sebesar $10,00 \%, 17,47 \%$, dan $6,34 \%$.

Untuk mewujudkan target-target tersebut, diperlukan upaya-upaya terstruktur dan terukur, yang harus dijabarkan ke dalam peta strategi yang mengakomodasi keinginan pemangku kepentingan berupa strategic outcomes yang terdiri dari :

1. Meningkatnya nilai tambah industri; 
2. Meningkatnya penguasaan pasar dalam dan luar negeri;

3. Kokohnya faktor-faktor penunjang pengembangan industri;

4. Meningkatnya kemampuan inovasi dan penguasaan teknologi industri yang hemat energi dan ramah lingkungan;

5. Menguat dan lengkapnya struktur industri;

6. Meningkatnya persebaran pembangunan industri;

7. Meningkatnya peran industri kecil dan menengah terhadap PDB.

Dalam rangka merealisasikan target-target tersebut, Kementerian

Perindustrian telah menetapkan dua pendekatan guna membangun daya saing industri nasional yang tersinergi dan terintegrasi antara pusat dan daerah. Beberapa hal yang dilakukan, antara lain :

1. Melalui pendekatan top-down dengan pengembangan 35 klaster industri prioritas yang direncanakan dari Pusat (by design) dan diikuti oleh partisipasi daerah yang dipilih berdasarkan daya saing internasional serta potensi yang dimiliki oleh bangsa Indonesia;

2. Melalui pendekatan bottom-up dengan penetapan kompetensi inti industri daerah yang merupakan keunggulan daerah, dimana pusat turut membangun pengembangannya, sehingga daerah memiliki daya saing. Pengembangan kompetensi inti di tingkat provinsi disebut sebagai Industri

Unggulan Provinsi dan di tingkat kabupaten/kota disebut Kompetensi Inti Industri Kabupaten/Kota. Pendekatan kedua ini merupakan pendekatan yang didasarkan pada semangat Otonomi Daerah. Penentuan pengembangan industri melalui penetapan klaster industri prioritas dan kompetensi inti industri daerah sangat diperlukan guna memberi kepastian dan mendapat dukungan dari seluruh sektor di bidang ekonomi termasuk dukungan perbankan.

Saat ini telah tersusun 35 Roadmap Pengembangan Klaster Industri Prioritas, yakni:

1. Industri Agro, terdiri atas:
a. Industri pengolahan kelapa sawit;
b. Industri karet dan barang karet;
c. Industri kakao;
d. Industri pengolahan kelapa;
e. Industri pengolahan kopi;
f. Industri gula;
g. Industri hasil Tembakau;
h. Industri pengolahan buah;
i. Industri furniture;
j. Industri pengolahan ikan;
k. Industri kertas; 
1. Industri pengolahan susu.

2. Industri Alat Angkut, meliputi:

a. Industri kendaraan bermotor;

b. Industri perkapalan;

c. Industri kedirgantaraan;

d. Industri perkeretaapian.

3. Industri Elektronika dan Telematika:

a. Industri elektronika;

b. Industri telekomunikasi;

c. Industri komputer dan peralatannya.

4. Basis Industri Manufaktur, mencakup:

a. Industri Material Dasar :

- Industri besi dan baja;

- Industri Semen;

- Industri petrokimia;

- Industri Keramik.

b. Industri Permesinan :

- Industri peralatan listrik dan mesin listrik;

- Industri mesin dan peralatan umum.

c. Industri Manufaktur Padat Tenaga Kerja :

- Industri tekstil dan produk tekstil;

- Industri alas kaki.

5. Industri Penunjang Industri Kreatif dan Kreatif Tertentu :

a. Industri perangkat lunak dan konten multimedia;

b. Industri fashion;

c. Industri kerajinan dan barang seni

6. Industri Kecil dan Menengah Tertentu :

a. Industri batu mulia dan perhiasan;

b. Industri garam rakyat;

c. Industri gerabah dan keramik hias;

d. Industri minyak atsiri;

e. Industri makanan ringan.

Salah satu tantangan utama yang dihadapi oleh industri nasional saat ini adalah masih rendahnya daya saing industri di pasar internasional. Menurut IMD Competitiveness Report pada tahun 2009 peringkat daya saing Indonesia berada pada posisi 42 dari 57 negara. Meskipun peringkat ini mengalami peningkatan jika dibandingkan tahun 2008 dimana Indonesia berada pada posisi 51 dari 55 negara. Namun demikian, posisi Indonesia masih jauh tertinggal jika dibandingkan dengan India (30), Korea (27) dan Malaysia (18). Kondisi yang kurang/lebih sama tetap bertahan hingga sekarang. 
Beberapa faktor yang menyebabkan rendahnya daya saing Indonesia adalah adanya peningkatan biaya energi, tingginya biaya ekonomi, serta belum memadainya layanan birokrasi. Tantangan lain yang dihadapi industri nasional adalah kelemahan struktural sektor industri itu sendiri, seperti masih lemahnya keterkaitan antar industri, baik antara industri hulu dan hilir maupun antara industri besar dengan industri kecil dan menengah, belum terbangunnya struktur klaster (industrial cluster) yang saling mendukung, adanya keterbatasan berproduksi barang setengah jadi dan komponen di dalam negeri, keterbatasan industri berteknologi tinggi, kesenjangan kemampuan ekonomi antar daerah, serta ketergantungan ekspor pada beberapa komoditas tertentu. Di samping itu proses industrialisasi bisa dilakukan kalau ada jaminan pasokan bahan baku dengan jenis/varitas, jumlah produksi dan harga yang stabil dan secara ekonomi layak. Oleh karena itu perlu adanya mobilisasi di tingkat petani/nelayan agar dapat menjamin kelangsungan produksi di sektor industri.

Dengan memerhatikan permasalahan yang bersifat nasional, baik di tingkat pusat mupun daerah dalam rangka peningkatan daya saing, maka pembangunan industri nasional yang sinergi dengan daerah dilakukan melalui dua pendekatan, yaitu:

1. Pendekatan top down, merupakan pembangunan industri yang direncanakan (by design) dengan memperhatikan prioritas dan memenuhi kriteria yang ditentukan secara nasional dan diikuti oleh partisipasi daerah. Kebijakan industri secara nasional dilakukan dengan menentukan industri prioritas (35 industri prioritas, dengan pendekatan klaster).

2. Pendekatan bottom-up yaitu melalui pemilihan dan penetapan kompetensi inti yang merupakan keunggulan daerah sehingga memiliki daya saing. Pengembangan kompetensi inti industri daerah diharapkan mampu meningkatkan daya saing industri nasional karena pengembangan industrinya lebih fokus dan lokusnya juga jelas, sehingga kinerja menjadi terukur dan mudah dievaluasi program pengembangannya.

Era globalisasi telah meyebabkan terjadinya perubahan paradigma, termasuk dalam dunia industri. Kepedulian masyarakat dunia akan kualitas produk industri dan kelestarian lingkungan telah memunculkan parameterparameter baru tentang industri sebagai bagian dari sistem sosial lingkungan.

\section{Agenda Riset Nasional (ARN) Teknologi Hankam}


Berdasarkan Agenda Riset Nasional (ARN) Teknologi Hankam, arah kebijakan dan prioritas utama untuk iptek teknlogi hankan diarahkan pada: (a) meningkatkan focus, kapasitas dan kapabilitas penelitian dan pengembangan dalam teknoogi pertahanan dan keamanan; (b) mempercepat proses difusi dan pemanfaatan hasil-hasil penelitian dan pengembangan dalam bidang teknologi pertahanan dan keamanan; (c) memperkuat kelembagaan iptek dalam teknologi pertahanan dan keamanan yang mencakup factor peneliti, fasilitas penelitian dan pengembangan, pola manajemen, fungsionalisasi organisasi penelitian dan pengembangan, kelengkapan dan kemutakhiran data kinerja iptek nasional, dan kemitraan; (d) menciptakan iklim inovasi dalam teknologi pertahanan dan keamanan dalam bentuk skema insentif yang sesuai; (e) menggunakan pendekatan demand pull sesuai dengan kebutuhan TNI dan Polri atau supply push untuk mendorong peningkatan kemampuan industry dan pertahanan serta keamanan nasional; (f) menyusun roadmap teknologi pertahanan dan keamanan yang jelas dalam focus tema riset; (g) mengutamakan penerapan teknologi pertahanan dan keamanan asional melalui pemanfaatan berbagai produk yang dihasilkan. Sementara itu, untuk tema riset difokuskan pada tujuh tema utama, yaitu (1) Tema Riset Teknologi Pendukung Daya Gerak, (2) Tema Riset Teknologi Pendukung Daya Tempur. (3) Tema Teknologi Pendukung KOmando, Kendali, Komunikasi, Komputasi, Pengamatan, dan Pengintaian (K4IPP), (4) Tema Riset Teknologi Pendukung BEKAL, (5) Tema Riset Pendukung Polri, (6) Tema Riset Teknologi Perlenkapan Khusus, (7) Tema Riset Kajian Strategis. "Kajian Teknis Pengunci Sasaran Bergerak" ini masuk ke dalam tema (7), yang topiknya adalah analisis strategi pertahanan nasional sesuai dengan kecenderungan teknologi. (Hartanto (ed.), 2013, p. 24-25).

\section{Kebijakan Negara terkait Revitalisasi Industri Pertahanan}

\section{Peraturan Presiden Nomor 42 Tahun 2010 tentang Komite Kebijakan Industri Pertahanan (KKIP)}


Perumusan kebijakan nasional yang bersifat strategis di bidang industry pertahanan yang meliputi kebijakan dalam penelitian, pengembangan dan perekayasaan, pendanaan, strategi pemasaran, pembinaan pemberdayaan, peningkatan sumber daya manusia, dan kerjasama luar negeri dalam industry pertahanan.

Berdasarkan Peraturan Presiden No. 42 tahun 2010 tentang KKIP pada pasal 3 ayat 1 berisi: komite kebijakan industry pertahanan bertugas untuk (a) merumuskan kebijakan nasional yang bersifat strategis di bidang industry pertahanan, (b) mengoordinasikan pelaksanaan dan pengendalian kebijakan nasional industry pertahanan, (c) mengoordinasikan kerja sama luar negeri dalam rangka memajukan dan mengembangkan industry pertahanan, dan (d) melaksanakan pemantauan dan ebaluasi pelaksanaan kebijakan undustri pertahanan. Dalam ayat 2 berbunyi: perumusan kebijakan nasional bersifat strategis di bidang industry pertahanan sebagaimana dimaksud pada ayat (1) huruf (a) meliputi kebijakan dalam penelitian, pengembangan dan perekayasaan, pendanaan, strategi pemasaran, pembinaan, pemberdayaan, peningkatan SDM dan kerja sama luar negeri dalam industry pertahanan. ${ }^{13}$

\section{Keputusan Presiden Nomor 35 Tahun 2011 tentang Percepatan Pemenuhan Kekuatan Pokok Minimal Alutsista TNI tahun 2010-2014}

Pemerintah melakukan percepatan pemenuhan kebutuhan kekuatan alutsita TNI yang merupakan prasyarat agar dapat melaksanakan tugas pokoknya. Dalam rangka hal tersebut Menteri Pertahanan menyususn kerangka kebutuhan tambhan pendanaan untuk tahun anggaran 2010-2014 paling banyak sebesar 57 triliun rupiah. Dari jumlah tersebut, sebesar 7 triliyn rupiah telah dialokasikan dalam Daftar Isian Pelaksanaan Anggaran Kementerian Pertahanan tahun anggaran 2010.

Keragnka pemenuhan kebutuhan alutsista disusun dengan berpedoman pada peraturan perundang-undangan serta prinsip-prinsip transparansi,

\footnotetext{
${ }^{13}$ Agus Hartanto, Kajian Kebijakan Alutsista Pertahanan dan Keamanan Republik Indonesia (Jakarta: LIPI Press, 2013), hal. 25.
} 
akuntabilitas, efisiensi, dan kehati-hatian. Pemenuhan kebutuhan alutsista TNI dilakukan dengan mengutamakan penggunaan produk nasional dalam rangka revitalisasi industry pertahanan dalam negeri.

Menteri Pertahanan menyususn daftar kebutusan alutsista TNI dan disampaikan kepada Menteri Keuangan dan Menteri Perencanaan Pembangunan Nasional/Kepala Bappenas, yang sekurang-kurangnya memuat informasi mengenai:

- Jenis dan spesifikasi teknis/jumlah pengadan barang dan jasa;

- Harga untuk setiap unit pengadaan barang dan jasa;

- Negara produsen barang dan jasa;

- Alih teknologi/produksi Bersama untuk kepentingan pengembangan industry pertahanan dalam negeri;

- Sifat pengadaan barang dan jasa; dan

- Rencana pengadaan dan perkiraan kebutuhan anggaran dalam setiap tahun.

Menteri Perencanaan Pembangunan Nasional/Kepala Bappenas menilai daftar kebutuhan sebagai bagian dari RKP dan RPJMN yang kemudian disampaikan kepada Menteri Keuangan. Menteri Keuangan menetapkan sumber pendanaan untuk membiayai pemenuhan kebutuhan tersebut. Hal ini dilakukan melalui mekanisme APBN dan menjadi bagian dari indikasi pagu Kemhan pada setiap tahun anggaran. Menteri Pertahanan mengatur tata cara penelenggara pemenuhan kbutuhan alutsista TNI, baik yang berasal dari produksi dalam negeri maupun produksi luar negeri, dengan mempertimbangkan upaya perbaikan mekanisme perencanaan, peningkatan kemampuan peyrapan anggaran, dan akuntabilitas pengelolaan anggaran. Menteri Pertahanan menyampaikan laporan kepada PResiden mengenai pencapaian kekuatan pokok minimal alutsista setiap semester pada tahun anggaran berjalan dengan tembusan kepada Menteri Keuangan dan Menteri Perencanaan Pembangunan Nasional/Kepla Bappenas. Selanjutnya laporan tersebut dievaluasi guna memproyeksikan kesinambungan pemenuhan kebutuhan pada tahun anggaran berikutnya. $^{14}$

\footnotetext{
${ }^{14} \mathrm{Ibid}$, hal 20-21.
} 


\section{Undang-Undang RI Nomor 16 Tahun 2012 tentang Industri Pertahanan}

Industri pertahanan merupakan bagian dari Industri nasional (pemerintah maupun swasta) yang produknya baik secara sendiri maupun kelompok, termasuk jasa pemeliharaaan dan perbaikan, atas penilaian pemerintah dapat dimanfaatkan untuk kepentingan pertahanan negara. Industri pertahanan, juga disebut industri militer, terdiri dari pemerintah dan industri komersial yang terlibat dalam penelitian, pengembangan, produksi, dan pelayanan peralatan dan fasilitas militer.

Industri pertahanan adalah sebagian dari tatanan industri nasional yang secara khusus memiliki kemampuan ataupun potensi yang dapat maupun dikembangkan untuk menghasilkan produk berupa sistem senjata, peralatan dan perlengkapan, dukungan administrasi/logistik ataupun jasa-jasa bagi kepentingan penyelenggaraan pertahanan negara.

Kriteria Industri Pertahanan yang telah ditetapkan oleh KKIP adalah sebagai berikut:

1. Industri pertahanan merupakan bagian dari industri nasional dan tergolong dalam kelompok industri strategis;

2. Industri pertahanan bersumber dari potensi industri nasional, baik milik pemerintah maupun swasta;

3. Industri pertahanan berkemampuan menghasilkan sistem senjata, peralatan dan dukungan logistik serta jasa-jasa bagi kepentingan pertahanan, disamping itu mampu menghasilkan produk-produk komersial dalam rangka mendukung pertumbuhan ekonomi nasional;

4. Industri pertahanan dalam pengelolaannya tidak terlepas dari prinsipprinsip ekonomi yang berlaku;

5. Industri pertahanan harus mampu mengkonversikan/ menstransformasikan kapasitas dan kapabilitas produksinya secara cepat selaras dengan tuntutan kebutuhan pertahanan khususnya dalam keadaan darurat/perang;

6. Industri pertahanan merupakan sandaran utama penyelenggaraan mobilitas industri dalam keadaan darurat perang;

7. Industri pertahanan atau setidak-tidaknya industri pendukung administrasi dan logistik harus diupayakan tersebar diseluruh wilayah nasional;

8. Industri pertahanan dikembangkan secara bertahap sesuai perkembangan postur Angkatan Bersenjata (TNI/Polri) dan tuntutan perkembangan teknologi sistem senjata; 
9. Industri pertahanan harus mampu berperan dalam mengurangi ketergantungan dari luar negeri dibidang pemenuhan kebutuhan sarana pertahanan (Alpalhankam).

10. Industri pertahanan harus didukung oleh kemampuan RDT \& E (Reseach Development Test \& Evaluation) yang tangguh dan konsisten terhadap perkembangan Iptek.

Industri pertahanan dapat terdiri dari industri milik pemerintah (BUMN) maupun milik swasta. Kelompok industri adalah bagian-bagian utama kegiatan industry, yaitu :

1. Kelompok industri hulu atau juga disebut kelompok industri dasar;

2. Kelompok industri hilir kelompok industri kecil.

Industri pertahanan harus mengembangkan dua jalur produksi, yaitu jalur memproduksi barang-barang umum dan memproduksi kebutuhan pertahanan negara. Perbandingan kapasitas antara jalur pertama dengan jalur kedua tergantung pada situasi yang dihadapi. Dalam keadaan damai jalur pertama lebih besar, sedangkan pada keadaan darurat/perang harus mampu dikembangkan dengan cepat melalui konvensi atau transformasi sejalan dengan tuntutan kebutuhan pertahanan negara yang meningkat. Karena industri pertahanan bergerak di bidang pemenuhan kebutuhan partahanan, maka diperlukan institusi pembina yang menjembatani kepentingan Angkatan Bersenjata sebagai konsumen dengan industri sebagai produsen. Dalam menghadapi keadaan darurat/perang, industri pertahanan merupakan sandaran utama bagi pelaksanaan mobilitas industri. Karena itu harus sudah terinventarisasi dan teridentifikasi sedini mungkin pada waktu damai.

Pada Undang-undang RI nomor 16 tahun 2012 dikatakan bahwa Industri Pertahanan (Indhan) adalah industri nasional yang terdiri atas badan usaha milik Negara (BUMN) dan badan usaha milik swasta (BUMS) baik secara sendiri maupun berkelompok yang ditetapkan oleh pemerintah untuk sebagian atau seluruhnya menghasilkan menghasilkan alat peralatan pertahanan dan keamanan, jasa pemeliharaan untuk memenuhi kepentingan strategis di bidang pertahanan dan keamanan yang berlokasi di wiliayah Negara Kesatuan Republik Indonesia (NKRI). Oleh karena itu, dibentuk suatu organisasi yang berfungsi merumuskan dan mengevaluasi kebijakan mengenai pengembangan dan 
pemanfaatan industri pertahanan yang bernama KKIP (Komite Kebijakan Industri Pertahanan) melalui Peraturan Presiden RI nomor 59 tahun 2013. KKIP merupakan organisasi pemerintah, khususnya pada kementrian pertahanan (Kemhan) yang bertugas untuk mengkoordinasikan kebijakan nasional dalam perencanaan, perumusan, pelaksanaan, pengendalian, sinkronisasi dan evaluasi yang terkait industri pertahanan. KKIP diharapkan bisa mewujudkan kemandirian industri pertahanan di Indonesia, khususnya untuk menyuplai kebutuhan internal TNI, termasuk merebut pasar regional maupun luar negeri lainnya, sehingga KKIP sebagai perencana penyelenggara Indhan bersifat strategis dengan mengakomodasikan kepentingan pengguna dan Indhan.

\section{E. PENUTUP}

Industry pertahanan di Indonesia sudah berkembang sejak awal kemerdekaan. Industry pertahanan tersebut diusahakan oleh swasta dan Badan Usaha Milik Negara (BUMN). Pada tahun 1980 an, pemerintah memberikan perhatian kepada insutri pertahanan dalam negeri dengan membentuk tim, dewan dan badan yang pada prinsipnya untuk mempercepat pembangunan industry pertahanan nasional. Pembentukan tim, dewan, dan badan dilakukan dengan beberapa Keputusan Presiden (Keppres) Nomor 40 Tahun 1980 tentng Tim Pembina Industri Hankam, Nomor 6 Tahun 1984 tentang Dewan Pembina Industri Strategis, Nomor 44 Tahun 1989 tentang Badan Pembina Industri Strategis, Nomor 56 Tahun 1989 tentang Dean Pembina Industri Strategis, Nomor 64 Tahun 1998 tentang Badan Pengelola BUMN dan PEnetapan PT BPIS. Perjalanan industry pertahanan Indonesia mengalami pasang surut sampai akhirnya terjadi krisis pada tahun 1998 seiring dengan krisis eknomi yang melanda Indonesia. Dengan terjadinya krisis, maka pada tahun 2001 dengan memperhatikan banyak BUMN yang tumbang, maka PT BPIS dibubarkan.

Kebijakan revitalisasi Industri Pertahanan di awali dengan pembentukan Komite Kebijakan Industri Pertahanan (KKIP) melalui Peraturan Presiden Nomor 42 Tahun 2010 disusul dengan lahirnya Undang-Undang Nomor 16 Tahun 2012 tentang Industri Pertahanan. Salah satu amanat Undang-undang terseut adalah 
pembentukan KKIP yang kemudian dikukuhkan dengan Keppres nomor 59 tahun 2013. Dengan adanya undang-Undang industry Pertahanan tersebut, maka keberadaan KKP akan lebih jelas dalam mendukung pengembangan industry pertahanan Indonesia. Tugas KKIP sebagaimana diamanatkan dalam keppres Nomor 42 Tahun 2010 yang diperbaharui dengan Keppres Nomor 59 Tahun 2013 adalah menetapkan kebijakan industry pertahanan nasional pada tatarasan strategis, mengoordinasikan pengelolaan kebijakan industry pertahanan nasional, mengoordinasikan kerjasama internasional unuk membangun dan mengembangkan industry pertahanan nasional, melaksanakan pemantauan dan evaluasi pengelolaan kebijakan industry pertahanan, menyusun dan membentuk rencana induk industry pertahanan jangka Panjang, menetapkan standar produk industry pertahanan, dan menetapkan kebijakan untuk pemenuhan kebutuhan alat peralatan pertahanan dan keamanan

\section{DAFTAR PUSTAKA}

\section{Buku}

Hartanto, Agus. Kajian Kebijakan Alutsista Pertahanan dan Keamanan Republik Indonesia. Jakarta : LIPI Press, 2013.

Karim, Silmy. Membangun Kemandirian Industri Pertahanan Indonesia. Jakarta : Kepustakaan Populer Gramedia, 2014.

Mary Kaldordan Ulrich Albrecht, The End of Military Fordism: Restructuring the Global Military Sector. London: United Nations University, 1998.

Richard A. Bitzinger, The Modern Defene Industry: Political, Economic, and Technological Issues. California: ABC CLIO, 2009.

Yusgiantoro, Purnomo. Ekonomi Pertahanan : Teori \& Praktik. Jakarta : PT Gramedia Pustaka Utama, 2014.

\section{Artikel Jurnal}

Angga Nurdin Rachmat, "Tantangan dan Peluang Perkembangan Teknologi Pertahanan Global Bagi Pembangunan Kekuatan Pertahanan Indonesia", Jurnal Pertahanan Vol 5 No 1, Juni 2017.

Beni Sukadis, "Peran Diplomasi Pertahanan Indonesia Dalam Kerjasama Pertahanan Indonesia Dan Amerika Serikat", Jurnal Ilmu Hubungan Internasional Mandala Vol 1 No 1 Januari-Juni 2017.

Denik Iswardani Witarti, dan Semmy Tyar Armandha, "Tinjauan Teoretis Konsepsi Pertahanan dan Keamanan Di Era Globalisasi Industri Pertahanan”, Jurnal Pertahanan Vol 5 No 3, Desember 2015. 
Helmi Tachejadi Soerjono, Muhamad Nur Affandi, Soni Akhmad Nulhaqim, "Perkembangan Alutsista Satuan Infanteri Pada Prioritas Pembangunan Minimum Essential Force (Mef)," Jurnal Kolaborasi Resolusi Konflik 01, No. 1 (September 2019). Universitas Padjadjaran, 2019, Bandung.

Ian Montratama, "Strategi Optimalisasi Pengadaan Sarana Pertahanan Bagi Industri Pertahanan Indonesia," Jurnal Pertahanan 04, No. 3 (Desember 2014), Kementerian Pertahanan RI, 2014, Jakarta. DOI: http://dx.doi.org/10.33172/jpbh.v4i3J.342.

Jerry Indrawan, "Perubahan Paradigma Pertahanan Indonesia Dari Pertahanan Teritorial Menjadi Pertahanan Maritim: Sebuah Usulan", Jurnal Pertahanan Vol 4 No 5 Agustus 2015.

Jonathan D. Caverley, "United States Hegemony and the New Economics of Defense", Journal of Security Studies Vol 16 No. 4, Oktober-Desember 2007.

Kina Media Ekuitas Produk Indonesia, "Disahkannya UU Industri PertahananTonggak Bangkitnya Industri Pertahanan Lokal" Edisi 2 Tahun 2012.

Lukman Fahmi Djarwono, "Pembangunan Industri Pertahanan Indonesia: Menuju Pemenuhan Target MEF atau Sekedar Menuju Arm Candy," Jurnal Defendonesia 02, No. 2 (Juni 2017). Lembaga Kajian Pertahanan untuk Kedaulatan NKRI, 2015, Jakarta.

Muradi, "Model Pendanaan Industri Pertahanan dan Peningkatan Sumber Daya Manusia," Jurnal Pertahanan 05, No. 2 (Agustus 2015). Kementerian Pertahanan RI, 2015, Jakarta. DOI: http://dx.doi.org/10.33172/ipbh.v5i2.365.

Pebri Tuwanto, "Politik Pembangunan Industri Pertahanan Nasional di Era Global," Jurnal Gema Keadilan 02, No. 1 (September 2015), Universitas Diponegoro, 2015, Semarang DOI: $\underline{10.3592 / 2}$.

\section{Undang-Undang}

Penyampaian Keterangan Pemerintah Atas Rancangan Undang-Undang tentang Anggaran Pendapatan Belanja Negara Tahun Anggaran 2012 beserta Nota Keuangannya di Depan Rapat Paripurna Dewan Perwakilan Rakyat Republik Indonesia, tanggal 16 Agustus 2011.

Peraturan Presiden Nomor 42 Tahun 2010 Tentang Komite Kebijakan Industri Pertahanan (KKIP)

Peraturan Presiden Republik Indonesia Nomor 59 Tahun 2013 Tentang Organisasi, Tata Kerja dan Sekretariat KKIP

Peraturan Presiden Nomor 28 Tahun 2008 tentang Kebijakan Industri Nasional.

Peraturan Pemerintah Nomor 35 Tahun 1986.

Peraturan Pemerintah Nomor 35 Tahun 2007.

Undang-Undang Nomor 18 tahun 2002 tentang Sistem Nasional Penelitian, Pengembangan dan Penerapan Ilmu Pengetahuan dan Teknologi.

Undang-Undang No.3 tahun 2002 tentang Pertahanan Negara.

Undang-Undang Nomor 16 Tahun 2012 Tentang Industri Pertahanan

Undang-Undang Nomor 23 Tahun 2003 tentang BUMN.

Undang-Undang Nomor 25 Tahun 2007 tentang Penanaman Modal. 
Kebijakan Negara Terkait Perkembangan Dan Revitalisasi Industri Pertahanan Indonesia Dari Masa Ke Masa Endro Tri Susdarwono, Ananda Setiawan, Yonimah Nurul Husna

e-ISSN : 2621-4105

Undang-Undang Nomor 3 Tahun 2002 tentang Pertahanan Negara.

Undang-Undang Nomor 5 Tahun 1984 Tentang Perindustrian. 